Sebastian Sikorski

Politechnika Warszawska

\title{
ROLA I ORGANIZACJA NARODOWEGO ORAZ WOJEWÓDZKICH FUNDUSZY OCHRONY ŚRODOWISKA I GOSPODARKI WODNEJ
}

\section{Wprowadzenie}

Prowadzenie efektywnych działań dotyczących ochrony środowiska wymaga zapewnienia odpowiednich źródeł finansowania, w szczególności przy realizacji kapitałochłonnych inwestycji o charakterze infrastrukturalnym. Dlatego dla prawidłowej realizacji zadań w tym obszarze niezbędne jest systemowe określenie organizacji wraz ze wskazaniem źródeł i zasad finansowania tego typu przedsięwzięć. W polskim systemie prawnym kluczową rolę w tym zakresie pełni obecnie Narodowy Fundusz Ochrony Środowiska i Gospodarki Wodnej wraz z funduszami wojewódzkimi. Ramy prawne organizacji i działalności tych funduszy zostały ustanowione w rozdziale 4 ustawy z dnia 27 kwietnia 2001 r. - Prawo ochrony środowiska ${ }^{1}$ (p.o.ś.). Regulacja ta od dnia uchwalenia była wielokrotnie nowelizowana. W konsekwencji na przestrzeni ponad $20 \mathrm{lat}^{2}$ modyfikacji uległa także organizacja i rola funduszy. ${ }^{3}$ Jedną z najistotniejszych zmian było nałożenie na fundusze obowiązku pełnego wykorzystania środków z Unii Europejskiej przeznaczonych na ochronę środowiska i gospodarki wodnej, ${ }^{4}$ co w praktyce oznaczało ich skierowanie na rozbudowę i modernizację infrastruktury ochrony środowiska. Biorąc pod uwagę rolę funduszy w systemowym finansowaniu ochrony środowiska, założeniem niniejszego artykułu jest przede wszystkim wyeksponowanie czytelnikowi zasad i zakresu ich działalności. Problematyka ta zostanie przedstawiona według systematyki przyjętej w samej

1 Ustawa z dnia 27 kwietnia 2001 r. - Prawo ochrony środowiska (Dz.U. z 2008 r. Nr 25, poz. 150 t.j. z późn. zm.).

2 S. Bochniarz, Finansowanie przedsięwzięć z zakresu ochrony przyrody przez Narodowy Fundusz Ochrony Środowiska i Gospodarki Wodnej, (w:) A. Mizgajski (red.), Finansowanie ochrony przyrody. Doświadczenia i perspektywy, Poznań 2003, s. 59.

3 Szerzej A. Hołuj, Wybrane instytucje i instrumenty finansowe w ochronie środowiska naturalnego, „Zeszyty naukowe Wyższej Szkoły Ekonomicznej w Bochni” 2006, Nr 5, s. 28 i n.

$4 \quad$ Art. 400 ust. 4 ustawy z dnia 3 października 2003 r. o zmianie ustawy - Prawo ochrony środowiska oraz niektórych innych ustaw (Dz.U. z 2003 r. Nr 190, poz. 1865 z późn. zm.). 
ustawie Prawo ochrony środowiska. W związku z tym wskazane zostaną tutaj cztery kluczowe obszary dotyczące organizacji funduszy, zasilenia ich w środki, cele jakie mogą być przez nie finansowane oraz dopuszczalne formy finansowania. $\mathrm{W}$ tak przyjętym układzie rozważań zasygnalizowane zostaną także pewne ograniczenia dotyczące zakresu finansowania przez fundusze. Wynikają one zarówno z samej ustawy Prawo ochrony środowiska, innych aktów normatywnych mających tutaj odpowiednie zastosowanie oraz z przyjętej praktyki. Szczególnego znaczenia nabierają tutaj zagadnienia wynikające $\mathrm{z}$ ustawy Prawo bankowe, ${ }^{5}$ co wynika zarówno z szerokiej możliwości stosowania tutaj bezpośrednio lub pośrednio instytucji prawa bankowego, jak i planów szerszego wykorzystania sektora bankowego przez Narodowy Fundusz Ochrony Środowiska i Gospodarki Wodnej. ${ }^{6}$

\section{Organizacja funduszy}

Do roku 2010 fundusze ochrony środowiska i gospodarki wodnej miały status funduszy celowych, które były ulokowane na wszystkich szczeblach podziału administracyjnego kraju. ${ }^{7} \mathrm{~W}$ związku z nowelizacją ustawy Prawo ochrony środowiska oraz niektórych ustaw z dnia 20 listopada $2009 \mathrm{r}^{8}{ }^{8}$ wprowadzono znaczące zmiany organizacyjne $\mathrm{w}$ modelu finansowania ochrony środowiska w Polsce. Likwidacji uległy fundusze na poziomie gmin i powiatów, a zadania będące dotychczas $\mathrm{w}$ ich właściwości zostały przekazane do realizacji bezpośrednio przez jednostki administracji samorządowej. Zgodnie z tym co zostało już powiedziane we wprowadzeniu, w obecnym stanie prawnym organizacja i zadania funduszy ochrony środowiska i gospodarki wodnej zostały uregulowane w rozdziale 4 ustawy Prawo ochrony środowiska. ${ }^{9}$ Zgodnie z postanowieniami art. 400 p.o.ś. Narodowy Fundusz Ochrony Środowiska i Gospodarki Wodnej uzyskał status państwowej osoby prawnej w rozumieniu art. 9 ust. 14 ustawy z dnia 27 sierpnia 2009 r. o finansach publicznych, ${ }^{10}$ natomiast wojewódzkie fundusze otrzymały status samorządowych osób prawnych. Jednocześnie ustawodawca w ust. 3 tego przepisu w sposób jednoznaczny wskazał, że fundusze wojewódzkie nie stanowią wojewódzkich samorządowych jednostek organizacyjnych w rozumieniu ustawy z dnia 5 czerwca 1998 r. o samorządzie województwa. ${ }^{11}$ Zdaniem K. Gruszeckiego ujęcie takie z jednej strony eliminuje

\footnotetext{
Ustawa z dnia 29 sierpnia 1997 r. Prawo bankowe (Dz.U. z 2012 r. Nr 1376 t.j. z późn. zm.).

Strategia działania Narodowego Funduszu Ochrony Środowiska i Gospodarki Wodnej na lata 2013-2016 z perspektywą do 2020 r. Zatwierdzona przez RN w dniu 26.09.2012 r., Warszawa 2012, s. 61.

Ustawa z dnia 27 kwietnia 2001 r. - Prawo ochrony środowiska (t.j. Dz.U. Nr 62, poz. 627 z późn. zm.).

Ustawa z dnia 20 listopada 2009 r. o zmianie ustawy Prawo ochrony środowiska oraz niektórych innych ustaw (Dz.U. Nr 215, poz. 1664).

9 Ustawa z dnia 27 kwietnia 2001 r. - Prawo ochrony środowiska (t.j. Dz.U. z 2008 r. Nr 25, poz. 150 z późn. zm.).

10 Ustawa z dnia 27 sierpnia 2009 r. o finansach publicznych (Dz.U. Nr 157, poz. 1240 z późn. zm.).

11 R. Marchewka, Wojewódzkie fundusze ochrony środowiska i gospodarki wodnej: zagadnienia administracyjnoprawne, „Kwartalnik Prawa Publicznego” 2002, 1-2/43; ustawa z dnia 5 czerwca 1998 r. o samorządzie województwa (Dz.U. z 2001 r. Nr 142, poz. 1590 t.j. z późn. zm.).
} 
wątpliwości, do jakiej grupy jednostek organizacyjnych powinny być fundusze te kwalifikowane. $Z$ drugiej zaś wskazuje, że województwa nie mają możliwości realizacji ich zadań w innej formie organizacyjnej. ${ }^{12}$ Autor ten wskazuje na jeszcze jedną istotną okoliczność. Mianowicie ustanowienie Narodowego Funduszu jako państwowej osoby prawnej, a wojewódzkich funduszy jako samorządowych osób prawnych powoduje, że postanowienia art. 10 ust. 1 ustawy o finansach publicznych (u.f.p.) ${ }^{13}$ znajdą tutaj odpowiednie zastosowanie. W praktyce oznacza to m.in. konieczność uwzględniania w działalności funduszy rozwiązań wynikających z art. 30 ust. 2 u.f.p., zgodnie z którym podstawą gospodarki finansowej państwowych i samorządowych osób prawnych jest plan finansowy. Natomiast zgodnie z ust. 3 tego przepisu plany finansowe państwowych i samorządowych osób prawnych muszą być sporządzane zgodnie z ustawami o ich utworzeniu, z uwzględnieniem przepisów ustawy o finansach publicznych. W konsekwencji projekty planów finansowych państwowych osób prawnych, o których mowa w art. 9 pkt 14 u.f.p. są przekazywane ministrowi właściwemu do spraw finansów w trybie i terminach określonych w przepisach dotyczących prac nad projektem ustawy budżetowej (art. 30 ust. 4 u.f.p.). Biorąc więc pod uwagę konieczność równoległego stosowania reguł wynikających z ustawy - Prawo ochrony środowiska, może powodować to znaczącą trudność natury praktycznej. ${ }^{14}$

Zgodnie z postanowieniami art. 400c p.o.ś organami Narodowego Funduszu są: Rada Nadzorcza oraz Zarząd. Analogiczne organy posiadają także wojewódzkie fundusze (art. 400e p.o.ś.). Rada Nadzorcza Narodowego Funduszu liczy do 12 osób powoływanych przez ministra właściwego do spraw ochrony środowiska. W jej skład wchodzą odpowiednio przedstawiciele ministrów właściwych do spraw: gospodarki, finansów publicznych oraz rozwoju regionalnego. Ponadto w skład Rady powoływani są dwaj przedstawiciele Komisji Wspólnej Rządu i Samorządu Terytorialnego oraz przedstawiciele organizacji ekologicznych o zasięgu ogólnokrajowym. W przypadku rad nadzorczych funduszy wojewódzkich organ ten składa się z 7 osób powoływanych i odwoływanych przez sejmiki województwa. ${ }^{15}$ Szczegółowy skład rad nadzorczych został określony w art. 400f p.o.ś., zgodnie z którym w skład tego organu wchodzą m.in.: regionalni dyrektorzy ochrony środowiska, przewodniczący regionalnych rad ochrony przyrody, przewodniczący komisji właściwych do spraw środowiska sejmików województw, dyrektorzy albo wicedyrektorzy departamentów do spraw ochrony środowiska urzędów marszałkowskich, przedstawiciele organizacji ekologicznych zgłoszeni przez organizacje działające i posiadające struktury organizacyjne na terenie danego województwa i cieszący się poparciem największej

K. Gruszecki, Prawo ochrony środowiska. Komentarz. wyd. 3, Warszawa 2011, s. 758.

Ustawa z dnia 27 sierpnia 2009 r. o finansach publicznych (Dz.U. Nr 157, poz. 1240 z późn. zm.).

Tak K. Gruszecki, Prawo ochrony środowiska..., op. cit., s. 759.

Zgodnie z przepisem art. 400 f ust. 8 p.o.ś. minister właściwy do spraw środowiska odwołuje tych członków rady nadzorczej, którzy w niej zasiadają w związku z pełnioną funkcją - dyrektorzy albo wicedyrektorzy departamentów do spraw ochrony środowiska urzędów marszałkowskich. 
liczby tych organizacji, przedstawiciele samorządów gospodarczych wybrani przez sejmiki województw spośród kandydatów zgłoszonych przez samorządy gospodarcze. Ustawodawca na gruncie art. 400h ust. 1 p.o.ś. wyznaczył Radzie Nadzorczej Narodowego Funduszu oraz radom nadzorczym funduszy wojewódzkich pewien wspólny zakres zadań, oczywiście z zastrzeżeniem ich właściwości działania. ${ }^{16} \mathrm{Na}-$ leży w tym miejscu wskazać zwłaszcza te uprawnienia, które w sposób bezpośredni przekładają się na zasady finansowania przedsięwzięć z zakresu ochrony środowiska. Po pierwsze, będzie to uprawnienie do ustalania kryteriów wyboru finansowanych przedsięwzięć. Po drugie, zatwierdzanie wniosków Zarządu Narodowego Funduszu oraz zarządów wojewódzkich funduszy o udzielenie pożyczek i dotacji z zastrzeżeniem, że ich wartość jednostkowa przekracza w przypadku pożyczki lub dotacji z Narodowego Funduszu równowartość odpowiednio kwoty 1 mln euro lub 500 tys. euro. Natomiast w przypadku pożyczki lub dotacji z wojewódzkiego funduszu ich jednostkowa wartość powinna przekroczyć $0,5 \%$ przychodów uzyskanych przez ten fundusz $\mathrm{w}$ roku poprzednim. Z kompetencji, które pośrednio przekładają się na finansowanie trzeba wskazać także na uprawnienie do zatwierdzania rocznych sprawozdań zarządów z działalności. Podkreślenia w tym miejscu wymagają jeszcze kompetencje rad do uchwalania czteroletnich planów (strategii) działania. ${ }^{17}$

Drugim z organów funduszy jest Zarząd. W przypadku Zarządu Narodowego Funduszu liczy on od 3 do 5 osób, w którym prezes i zastępcy powoływani są przez ministra właściwego do spraw ochrony środowiska. W przypadku funduszy wojewódzkich zarząd liczy od 2 do 5 osób powoływanych przez zarządy województw na wniosek rad nadzorczych. Zarówno w Narodowym, jak i wojewódzkich funduszach to prezes zarządu reprezentuje fundusz na zewnątrz oraz wykonuje przypisane mu obowiązki z zakresu gospodarowania majątkiem funduszu. Spośród kompetencji zarządu dotyczących zasad finansowania zadań ochrony środowiska należy wskazać przede wszystkim opracowywanie planów działania funduszy, opracowywanie projektów rocznych planów finansowych oraz dokonywanie wyboru przedsięwzięć do finansowania ze środków funduszy. ${ }^{18} \mathrm{~W}$ tym aspekcie istotne są także uprawnienia zarządów w zakresie kontroli wykorzystania środków udostępnionych przez fundusze w formie dotacji bądź pożyczek.

Z punktu widzenia przedstawionych na wstępie założeń niniejszego artykułu szczególnie istotne jest wskazanie rozbieżności w określeniu przez ustawodawcę kompetencji poszczególnych organów, które bezpośrednio dotyczą finansowania

16 Uprawnienia odrębne dla rady nadzorczej Narodowego Funduszu oraz rad nadzorczych wojewódzkich funduszy zostały określone w art. 400 h ust. 2 i 4 p.o.ś.

17 Strategia działania Narodowego Funduszu Ochrony Środowiska i Gospodarki Wodnej na lata 2013-2016 z perspektywą do 2020 r. Zatwierdzona przez RN w dniu 26.09.2012 r., Warszawa 2012; Wspólna strategia działania Narodowego Funduszu i wojewódzkich funduszy ochrony środowiska i gospodarki wodnej na lata 2013-2016 z perspektywą do 2020 r., Warszawa 2012 r.

Szczegółowy zakres kompetencji zarządu narodowego i wojewódzkich funduszy ochrony środowiska został określony w przepisie art. 400i oraz 400k p.o.ś. 
Rola i organizacja Narodowego oraz wojewódzkich funduszy ochrony środowiska...

poszczególnych przedsięwzięć. Jak słusznie wskazuje K. Gruszecki na tle analizy kompetencji rad nadzorczych i zarządów funduszy należy stwierdzić, że niektóre $\mathrm{z}$ nich mogą być wspólne. Ustawodawca nie wskazał jednoznacznie, jaki organ Narodowego Funduszu zatwierdza wnioski o udzielnie pożyczek i dotacji, których wartość jednostkowa wynosi odpowiednio poniżej równowartość $1 \mathrm{mln}$ euro dla pożyczek i 500 tys. euro dla dotacji. Podobnie w przypadku kompetencji organów funduszy wojewódzkich nie określono organu właściwego do zatwierdzania wniosków o pożyczki i dotacje poniżej $0,5 \%$ przychodów uzyskanych przez konkretny fundusz w roku poprzednim. Należy założyć, że kwoty te będą zatwierdzane w ramach kompetencji zarządów funduszy. Podobne wątpliwości mają miejsce w przypadku kompetencji umorzenia pożyczek. W art. 411 ust. 3 p.o.ś. określono jedynie dopuszczalność częściowego umorzenia pożyczki, nie wskazując jednak, jaki organ władny jest taką decyzję podjąć. W konsekwencji zdaniem K. Gruszeckiego ${ }^{19}$ rozwiązania tego problemu należy szukać w statutach funduszy, ${ }^{20}$ które określają szczegółowe zasady organizacji i trybu ich działania.

\section{III. Źródła finansowania funduszy}

Obok adekwatnej struktury organizacyjno-prawnej dla prawidłowego funkcjonowania i realizacja celów funduszy niezbędne jest wskazanie źródeł ich finansowania. Zostały one określone przez ustawodawcę w art. 401 p.o.ś., zgodnie z którym są to opłaty za korzystanie ze środowiska oraz administracyjne kary pieniężne. Ustawodawca wskazał także kilka rodzajów przychodów funduszy o charakterze fakultatywnym. Przede wszystkim należy tutaj wskazać środki pochodzące z budżetu Unii Europejskiej oraz środki pochodzące z innych zagranicznych źródeł, które mają charakter bezzwrotny. Ponadto mogą to być dobrowolne wpłaty, zapisy, darowizny, świadczenia rzeczowe i środki pochodzące z fundacji oraz wpływy z przedsięwzięć organizowanych na rzecz ochrony środowiska i gospodarki wodnej. Do tego rodzaju przychodów należą również ewentualne wpływy z tytułu dotacji z budżetu państwa, emisji obligacji własnych oraz inne przychody związane z działalnością tych funduszy. Zgodnie z ust. 6 wyżej przywołanego przepisu, fundusze mają także możliwość zaciągania kredytów i pożyczek.

Obok wyżej wskazanych źródeł finansowania, ustawodawca na gruncie przepisu art. 401 ust. 7 i 8 p.o.ś. wskazał te rodzaje kar i opłat, które stanowią odpowiednio wyłączne źródło przychodu Narodowego Funduszu bądź funduszy wojewódzkich. Trzeba w tym miejscu także podkreślić, że przywołany powyżej przepis art. 401 p.o.ś. nie wyczerpuje wszystkich źródeł finansowania. Zgodnie bowiem z przepisem

19 K. Gruszecki, Prawo ochrony środowiska, op. cit., s. 840.

20 Statut Narodowego Funduszu został nadany rozporządzeniem Ministra Środowiska z dnia 7 grudnia 2010 r. w sprawie nadania statutu Narodowemu Funduszowi Ochrony Środowiska i Gospodarki Wodnej (Dz.U. Nr 240, poz. 1609). 
art. 401 d p.o.ś. Narodowy Fundusz zasilany jest także m.in. wpływami ze sprzedaży jednostek przyznanej emisji zawieranych na podstawie ustawy z dnia 17 lipca 2009 r. o systemie zarządzania emisjami gazów cieplarnianych i innych substancji. ${ }^{21}$ Natomiast proporcje podziału tych środków zostały określone w art. 402 ust. 4-7 p.o.ś. Przedstawiając źródła przychodów funduszy warto się także przyjrzeć kilku aspektom dotyczącym ich struktury. Z opracowania sporządzonego przez E. Mazur-Wierzbicką ${ }^{22}$ na podstawie danych Głównego Urzędu Statystycznego za okres 1990-2010 r. wynika, że wpływy do funduszy z tytułu opłat wynosiły od 26,6 mln zł w roku 1990 do $1944,2 \mathrm{mln}$ zł w roku 2010. Były to opłaty pochodzące z następujących obszarów: gospodarki ściekowej i ochrony wód, ochrony powietrza atmosferycznego i klimatu, gospodarki odpadami. Przy czym na przestrzeni lat zmianie ulegał ich udział. Widoczny jest zwłaszcza znaczny wzrost procentowy wpływów $\mathrm{z}$ opłat pochodzących $\mathrm{z}$ gospodarki odpadami. Natomiast odnotowano spadek udziału procentowego wpływów z opłat z pozostałych dwóch obszarów. Jeśli chodzi natomiast o wpływy $\mathrm{z}$ kar, to $\mathrm{w}$ analogicznym okresie wyniosły one odpowiednio od 1,8 mln zł w roku 1990 do $6 \mathrm{mln}$ zł w roku 2010. Przy czym należy w tym miejscu wyraźnie zauważyć, że nie mamy tutaj do czynienia z progresją. W roku 2004 wpływy z tytułu kar wyniosły bowiem aż $38,3 \mathrm{mln}$ zł. Na tle tych danych nasuwają się dwa wnioski. Po pierwsze, widoczna jest rażąca dysproporcja pomiędzy wpływami z tytułu opłat środowiskowych a wpływami z nakładanych kar. Po drugie, jak słusznie wskazuje E. Mazur-Wierzbicka widać istotny problem ze ściągalnością kar. ${ }^{23} \mathrm{Na}$ interesującą okoliczność w tym kontekście wskazuje K. Gruszecki, który słusznie podkreśla, iż nie budzi wątpliwości właściwość organów odpowiedzialnych za windykację i dystrybucję opłat z tytułu korzystania ze środowiska i administracyjnych kar pieniężnych oraz zasad ich rozliczeń środków. Zgodnie z przepisem art. 402 ust. 1 p.o.s. właściwe są tutaj odpowiednio: zarząd województwa w przypadku opłat i wojewódzki inspektor ochrony środowiska w przypadku kar. Przywołany przepis dokładnie określa także rozwiązania rachunkowe dotyczące gromadzenia tych środków. Natomiast zdaniem tego autora nie do końca unormowana została kwestia konsekwencji braku właściwego wywiązywania się przez te organy z ciążących na nich w tym zakresie obowiązków. W treści przepisu art. 402 ust. 3 p.o.ś. zastrzeżono co prawda odsetki za nieterminowe przekazanie wpływów. Jednak w przepisie tym nie określono sposobu domagania się przekazania środków na rzecz poszczególnych funduszy. W konsekwencji może jego zdaniem dojść do sytuacji, w której środki wpłynęły na rachunki bankowe uprawnionych organów, ale nie zostały przekazane

21 Ustawa z dnia 17 lipca 2009 r. o systemie zarządzania emisjami gazów cieplarnianych i innych substancji (Dz.U. Nr 130, poz. 1070 z późn. zm.); F. Piontka (red.), Rola i znaczenie funduszy ochrony środowiska i gospodarki wodnej po integracji Polski z Unią Europejską, Komitet Naukowy przy Prezydium PAN „Człowiek i Środowisko" 2004, s. 93 i n.

E. Mazur-Wierzbicka, Ochrona środowiska a integracja europejska: doświadczenia polskie, Warszawa 2012, s. 215-216.

23 Ibidem, s. 215-216. 
Rola i organizacja Narodowego oraz wojewódzkich funduszy ochrony środowiska...

dalej. Celem zobrazowania tego problemu K. Gruszecki przywołuje orzeczenie Sądu Najwyższego z dnia 23 lutego 1995 r., ${ }^{24}$ które pomimo jego wydania na gruncie innego stanu prawnego zachowuje w pełni swoją aktualność do obecnie działających funduszy. Skład orzekający stwierdził w nim, że: „Gmina może dochodzić na drodze sądowej roszczenia przeciwko Skarbowi Państwa o przekazanie dochodu gminnych funduszy w wysokości 10\% wpływów z opłat i kar...”. W uzasadnieniu swojego stanowiska Sąd Najwyższy przyjął, że w tym przypadku ma miejsce stosunek władczy, który zachodzi między wojewodą a jednostką organizacyjną zobowiązaną do uiszczenia opłat i kar. Gmina natomiast nie jest stroną tego stosunku, ponieważ pomiędzy gminą a zobowiązaną jednostką organizacyjną nie zachodzi żaden stosunek prawny. W konsekwencji uzasadnia to wystąpienie na drogę postępowania przed sądami powszechnymi. ${ }^{25}$

\section{Cele finansowane przez fundusze}

Środki będące w dyspozycji funduszy przeznaczone są na 42 zadania, które zostały określone w art. 400 a p.o.ś. w sposób niezwykle kazuistyczny. Zdaniem S. Urbana chcąc usystematyzować te zadania należałoby przyjąć, że można je podzielić na zadania z zakresu: ochrony środowiska, gospodarki wodnej i ochrony wód, ochrony powierzchni ziemi i gospodarki odpadami, ochrony zdrowia, a także rozwoju, gromadzenia i upowszechniania wiedzy oraz pozostałe. ${ }^{26}$ Autor ten dokonuje także spostrzeżenia będącego jak wskazuje swoistym znakiem czasu, a mianowicie, że określając katalog zadań finansowanych przez fundusze ustawodawca aż trzykrotne wskazuje na zadania związane z przygotowaniem i prowadzeniem inwestycji realizowanych z udziałem środków pochodzących ze źródeł zagranicznych (przede wszystkim z budżetu Unii Europejskiej). ${ }^{27}$ Kazuistyka, jaką posłużył się ustawodawca mogłaby sugerować zamknięty charakter wskazanego wyżej katalogu zadań. Przeciwko takiej interpretacji przemawiają jednak dwa argumenty wnikające wprost z ustawy. ${ }^{28}$ Po pierwsze, w treści samego art. 400 a pkt 42 p.o.ś. zostało zawarte wskazanie, iż środki będące w dyspozycji funduszy mogą być przeznaczone na ,inne zadania służące ochronie środowiska i gospodarce wodnej, wynikające z zasady zrównoważonego rozwoju i polityki ekologicznej państwa". Takie sformułowanie wyraźnie więc wskazuje otwarty charakter katalogu zadań. ${ }^{29}$ Po drugie, po-

24 Uchwała SN z dnia 23 lutego 1995 r., III CZP 14/95, OSNC 1995, nr 6, poz. 90.

25 K. Gruszecki, Prawo ochrony środowiska..., op. cit., s. 816-817.

26 S. Urban, (w:) M. Górski, M. Pchałek, W. Radecki, J. Jerzmański, M. Bar, S. Urban, J. Jendrośka, Prawo ochrony środowiska. Komentarz, Warszawa 2011, s. 1297.

27 Ibidem, s. 1297.

28 Tak też Z. Bukowski, E.K. Czech, K. Korpus, B. Rakoczy, Prawo ochrony środowiska. Komentarz, Warszawa 2013, s. 713.

29 Zdaniem S. Urbana art. 400 a ust. 1 pkt 42 p.o.ś. daje sporą swobodę interpretacyjną przy określaniu celów finansowania - S. Urban, (w:) M. Górski, M. Pchałek, W. Radecki, J. Jerzmański, M. Bar, S. Urban, J. Jendrośka, Prawo ochrony środowiska..., op. cit., s. 1297. 
stanowienia art. 400 a p.o.ś. nie wyczerpują wszystkich zadań finansowanych przez fundusze. Zgodnie bowiem z art. 400 b ust. 3 p.o.ś. Narodowy Fundusz Ochrony Środowiska i Gospodarki Wodnej wykonuje również zadania Krajowego operatora systemu zielonych inwestycji, określone w ustawie z dnia 17 lipca 2009 r. o systemie zarządzania emisjami gazów cieplarnianych i innych substancji. ${ }^{30}$ Ponadto zgodnie z przepisem art. 410 a p.o.ś. Narodowy Fundusz finansuje także wykonywany przez przedsiębiorców demontaż pojazdów wycofanych z eksploatacji. Finansowane mogą być również inwestycje dotyczące demontażu pojazdów, gospodarowanie odpadami powstałymi przy jego wykonywaniu oraz działania związane ze zbieraniem pojazdów wycofanych z eksploatacji przez przedsiębiorców. ${ }^{31}$ Analizując cele, które mogą być finansowane środkami funduszy należy także wskazać szczególny przypadek ustanowiony przez ustawodawcę w przepisie art. 410d p.o.ś., zgodnie z którym ze środków Narodowego Funduszu mogą być finansowane także przedsięwzięcia realizowane poza granicami kraju, po uzyskaniu zgody ministra właściwego do spraw środowiska. Minister udzielając takiej zgody zobowiązany jest wziąć pod uwagę konieczność realizacji zasady zrównoważonego rozwoju, polityki ekologicznej państwa oraz zobowiązań określonych w prawie Unii Europejskiej i umowach międzynarodowych, których stroną jest Rzeczpospolita Polska. ${ }^{32}$ Inne cele zlokalizowane poza granicami kraju, a podlegające finansowaniu ze środków Narodowego Funduszu zostały określone w przepisie art. 410e p.o.ś. Zgodnie z tym przepisem mogą być finansowane także przedsięwzięcia nie mające charakteru projektów bądź inwestycji z zakresu ochrony środowiska. W tym przypadku również wymagana jest zgoda ministra właściwego do spraw ochrony środowiska.

Na tle ustawowego określenia celów widać także podział na cele finansowane na szczeblu centralnym oraz cele realizowane na poziomie wojewódzkim. Ujęcie takie wynika zresztą wprost z przepisu art. 400b p.o.ś., w którym określono, jakie cele powinny być finansowane ze środków Narodowego Funduszu, a jakie ze środków funduszy wojewódzkich. ${ }^{33}$ Jak wskazuje K. Gruszecki na tle tak sformułowanego przepisu uprawniony byłby wniosek, że wymieniony w nim Narodowy Fundusz (państwowa osoba prawna) oraz wojewódzkie fundusze (samorządowe osoby prawne) nie mogą współfinansować tych samych celów. Jego zdaniem wniosek taki byłby jednak nie do końca uprawniony. W konsekwencji przyjmuje on, że realizacja jednego zadania (oczywiście z zakresu ochrony środowiska) może bowiem służyć

Ustawa z 17 lipca 2009 r. o systemie zarządzania emisjami gazów cieplarnianych i innych substancji (Dz.U. Nr 130, poz. 1070 z późn. zm.).

31 W przepisie art. 410 a p.o.ś. zostały doprecyzowane szczegółowe warunki, jakie muszą spełnić przedsiębiorcy ubiegający się o finansowanie tego rodzaju działalności.

32 S. Urban, (w:) M. Górski, M. Pchałek, W. Radecki, J. Jerzmański, M. Bar, S. Urban, J. Jendrośka, Prawo ochrony środowiska..., op. cit., s. 1344.

33 Pomimo iż analiza dotyczy finansowania realizowanego wyłącznie przez Narodowy oraz wojewódzkie fundusze ochrony środowiska i gospodarki wodnej należy wskazać, że katalog celów finansowania określony w przepisie art. 400 a p.o.ś. kierowany jest również do powiatów i gmin, co wynika z przepisu art. 403 tej ustawy. 
Rola i organizacja Narodowego oraz wojewódzkich funduszy ochrony środowiska...

realizacji różnych celów, które pozostają w gestii zarówno Narodowego Funduszu, jak i wojewódzkich funduszy. ${ }^{34}$

Dokonując charakterystyki ustawowych celów, jakie mogą być finansowane ze środków z funduszy ochrony środowiska i gospodarki wodnej nieodzowne jest w tym miejscu wskazanie dotychczasowych rezultatów w tym zakresie. $Z$ analizy przeprowadzonej przez E. Mazur-Wierzbicką wynika, że fundusze ochrony środowiska i gospodarki wodnej dotychczas w największym stopniu finansowały przedsięwzięcia z obszaru gospodarki ściekowej i ochrony wód. Zakres finansowania tego obszaru kształtował się odpowiednio od 38,7\% całkowitych wydatków funduszy w roku 2003 do 60,1\% w 2009 r. Na drugim miejscu znalazł się obszar ochrony powietrza atmosferycznego i klimatu, który w latach 2004-2006 stanowił 21\% wszystkich wydatków funduszy. Od roku 2008 widoczny jest jednak spadek finansowania tego obszaru, którego udział w globalnych wydatkach w roku 2010 wyniósł jedynie $14,7 \%$. Kolejne miejsce zajął obszar gospodarki odpadami, który w analizowanym okresie, tj. w latach 2002-2010 wyniósł średnio 7\% . ${ }^{35}$

\section{Formy finansowania}

Z dotychczasowych rozważań wynika, że dla prawidłowej realizacji zadań przez fundusze ochrony środowiska i gospodarki wodnej niezbędne było określenie przez ustawodawcę kilku kluczowych aspektów. Chodzi o wyznaczenie pewnych ram organizacyjnych funduszy (ze wskazaniem kompetencji ich organów), precyzyjne określenie źródeł zaopatrzenia ich w środki finansowe oraz określenie celów podlegających finansowaniu. Ostatnim elementem niezbędnym do prawidłowego działania funduszy jest określenie instrumentarium finansowego, jakimi mogą się one posługiwać. Taki katalog został określony na gruncie art. 411 p.o.ś. Z przepisu tego wynika, że ustawodawca zdecydował na szerokie jego ujęcie. Został dokonany jednak podział na instrumenty, które mogą być wykorzystywane przez fundusze zarówno na szczeblu centralnym, jak i wojewódzkim oraz formy finansowania zastrzeżone wyłącznie do właściwości Narodowego Funduszu.

Podstawową formą finansowania wspólną Narodowemu i wojewódzkim funduszom jest pożyczka. Wynika to z treści uzasadnienia do ustawy z 2009 r. o zmianie ustawy - Prawo ochrony środowiska i niektórych innych ustaw, w którym projektodawcy wskazali, że założeniem jest „stała odtwarzalność”36 środków, czyli, aby mo-

34 K. Gruszecki, Prawo ochrony środowiska..., op. cit., s. 763.

35 E. Mazur-Wierzbicka, Ochrona środowiska..., op. cit., s. 217.

36 Warto w tym miejscu wskazać, że w latach 2002-2010 fundusze ochrony środowiska i gospodarki wodnej udzielały co prawda przede wszystkim finansowania zwrotnego. Jednak proporcje między pomocą zwrotną a bezzwrotną różnie się układały wykazując w niektórych latach minimalną różnicę. Natomiast w roku 2002 udział finansowania bezzwrotnego uzyskał wręcz przewagę i wyniósł 53,4\% w całości wydatkowanych środków. Trzeba jednak przyznać, że była to sytuacja wyjątkowa - Szerzej E. Mazur-Wierzbicka, Ochrona środowiska..., op. cit. s. 218-219. 
gły one być wielokrotnie wykorzystane. ${ }^{37}$ Należy podkreślić, że z treści art. 411 ust. 1 pkt 1 p.o.ś. wynika, iż pożyczki te mają być oprocentowane. Jednak ustawodawca nie wskazał zasad ustalania wysokości tego oprocentowania i jak słusznie podkreśla K. Gruszecki należy przyjąć, że będzie to stanowić przedmiot negocjacji albo zostanie określone w samych zasadach udzielania pożyczek. Autor ten wskazuje także na dopuszczalność zróżnicowania wysokości oprocentowania pożyczek w zależności od dofinansowywanych zadań, a w szczególnie uzasadnionych przypadkach istnieje jego zdaniem także możliwość zmiany jego wysokości, na przykład za zgodą rady nadzorczej. ${ }^{38}$ Pomimo wskazanego wyżej założenia odtwarzalności środków będących w dyspozycji funduszy ustawodawca przewidział w treści art. 411 ust. 3 p.o.ś. możliwość ich umorzenia. Zostało to jednak obwarowane kilkoma warunkami. Po pierwsze, możliwość umorzenia została wyłączona dla pożyczek przeznaczonych na zachowanie płynności finansowej przedsięwzięć współfinansowanych ze środków Unii Europejskiej. Po drugie, umorzenie takie może mieć charakter jedynie częściowy. Podkreślić jednak należy, że nie została określona maksymalna wysokość takiego umorzenia. Dlatego w doktrynie wskazuje się, że będzie to w gestii każdego z funduszy, które powinny jednak (ze względu na bezpieczeństwo obrotu) wyznaczyć precyzyjne ramy w tym zakresie. ${ }^{39}$ Po trzecie, umorzenie pożyczki zostało uwarunkowane terminową realizacją finansowanego zadania oraz osiągnięciem zamierzonego efektu. Ustawodawca posłużył się więc kryteriami stwarzającymi szerokie pole do interpretacji. Dlatego kluczowego znaczenia w tej kwestii nabiorą przywołane już wyżej wewnętrzne zasady udzielania pożyczek oraz treść indywidualnych umów o pożyczkę. ${ }^{40}$ Biorąc pod uwagę złożoność niektórych projektów w praktyce będzie to zapewne oznaczać konieczność wprowadzenia do umów pożyczek słowników precyzyjnie definiujących te pojęcia wraz z dołączeniem szczegółowej dokumentacji, na przykład technicznej. Oczywiście nie sposób wyeliminować całkowicie elementu ocennego tych pojęć, istotne jest jednak maksymalne ograniczenie zakresu dopuszczalnej interpretacji. Jest to zarówno w interesie funduszy, jak i pożyczkobiorców. Przywołany wyżej autor dostrzega na gruncie art. 411 ust. 3 p.o.ś. także możliwość wprowadzenia przez każdy fundusz dodatkowych niewynikających wprost z ustawy kryteriów, jak na przykład terminowa spłata zobowiązania. ${ }^{41}$ Pogląd ten wydaje się jednak zbyt daleko idący. Ustawodawca nie zawarł bowiem wskazania co do otwartego katalogu przesłanek umorzenia pożyczki.

Kolejnym sposobem finansowania przez fundusze są zgodnie $\mathrm{z}$ art. 411 ust. 1 pkt 2 p.o.ś dotacje. Mogą one być udzielane w formie dopłat do oprocentowania kredytów bankowych lub ceny wykupu obligacji, dopłat do demontażu pojazdów środowiska..., op. cit., s. 1290.

K. Gruszecki, Prawo ochrony środowiska..., op. cit., s. 839.

Tak K. Gruszecki, Prawo ochrony środowiska..., op. cit., s. 840.

Ibidem, s. 840.

Ibidem, s. 840 . 
Rola i organizacja Narodowego oraz wojewódzkich funduszy ochrony środowiska...

wycofanych z eksploatacji oraz częściowych spłat kapitału kredytów bankowych. $\mathrm{Z}$ brzmienia art. 411 ust. 1 pkt 2 p.o.ś. wynika, że wyliczenie celów, na jakie może być udzielona dotacja ma charakter katalogu otwartego. Oznacza to, że w pozostałych przypadkach to fundusze na podstawie indywidualnych decyzji będą określać krąg beneficjentów i rodzaje przedsięwzięć w ten sposób finansowanych. ${ }^{42}$ Podobnie jak w przypadku pożyczek ustawodawca pozostawił funduszom luz decyzyjny w zakresie wysokości finansowania oraz określenia przypadków konieczności ich zwrotu. Kwestie te powinny również być szczegółowo określone w umowach indywidualnych o udzielenie dotacji. W tym miejscu należy jednak wskazać dwie istotne kwestie wynikające wprost z ustawy, które dotyczą dotacji przeznaczonych na demontaż pojazdów wycofanych z eksploatacji. Zgodnie z postanowieniami art. 411 ust. 1f p.o.ś. powinien być w tym przypadku sporządzony, a następnie zatwierdzony przez Narodowy Fundusz szczegółowy harmonogram prac likwidacyjnych i rekultywacyjnych obejmujący rodzaj i zakres zadań, wysokość niezbędnych nakładów i czas ich realizacji. Ponadto zgodnie z art. 411 ust. 1g p.o.ś. dotacja wykorzystana z naruszeniem wskazanego wyżej harmonogramu podlega zwrotowi do Narodowego Funduszu.

Ustawodawca wprowadził także wymóg wspólny zarówno dla dotacji, jak i pożyczek. Zgodnie z art. 411 ust. 7 p.o.ś. w przypadku wniosków o przyznanie finansowania w tej właśnie formie w kwocie powyżej równowartości $10 \mathrm{mln}$ euro niezbędne jest dołączenie uzasadnienia obejmującego analizę alternatywnych rozwiązań w przypadku środków technicznych, które jedynie służą ograniczeniu negatywnego oddziaływania na środowisko.

Kolejną formą finansowania zgodnie z postanowieniami art. 411 ust. 1 pkt 3 p.o.ś. są nagrody za działalność na rzecz ochrony środowiska i gospodarki wodnej nie związaną z wykonywaniem obowiązków pracowników administracji rządowej i samorządowej. W przypadku tego rodzaju finansowania odstąpiono jednak zgodnie z art. 411 ust. 9 p.o.ś. od wymogu umowy. W literaturze przedmiotu zauważono, że użycie przez ustawodawcę w tym przepisie określenia: ,jeżeli ich fundatorem jest Narodowy Fundusz lub wojewódzkie fundusze" wskazuje, że nie muszą być one wręczane w konkursach organizowanych bezpośrednio przez fundusze. Istotna jest jedynie okoliczność, aby fundusze były fundatorem nagrody. Podkreślić również należy, że na tej podstawie nie mogą być finansowane inne koszty związane z organizacją konkursów przez inne podmioty. ${ }^{43}$ Fundusze ochrony środowiska i gospodarki wodnej mogą także nabywać udziały lub akcje w niektórych spółkach prawa handlowego. Zgodnie z art. 411a p.o.ś. możliwość ta dotyczy tylko tych spółek, których statutowym bądź ustawowym przedmiotem działalności jest ochrona środowiska i gospodarka wodna. Ustawodawca na gruncie ust. 2 wyżej przywołanego prze- 
pisu dopuścił jednak w tym zakresie wyjątek polegający na możliwości nabywania udziałów i akcji w spółkach z innym przedmiotem działalności w zamian za nieściągalne wierzytelności wynikające z umów. Możliwość ta została jednak przewidziana wyłącznie dla Narodowego Funduszu. Na tle tego przepisu należy poczynić kilka uwag. Po pierwsze, jak słusznie wskazuje K. Gruszecki wbrew pozorom bardzo wąsko został określony zakres przedmiotu działalności spółek, w którym fundusze mogą nabywać udziały. Ustawodawca konstruując ten przepis posłużył się bowiem spójnikiem „i”. Zgodnie więc z wykładnią gramatyczną należy przyjąć, że chodzi wyłącznie o spółki, które prowadzą działalność zarówno w zakresie ochrony środowiska, jak i gospodarki wodnej, co w praktyce występuje rzadko z uwagi na fakt, że gospodarka wodna nie jest często zbieżna $\mathrm{z}$ interesami ochrony środowiska. ${ }^{44} \mathrm{Po}$ drugie, wątpliwości co do ratio legis może powodować nałożenie wyłącznie na Narodowy Fundusz obowiązku uzyskania zgody organu sprawującego nadzór (w tym przypadku ministra właściwego do spraw ochrony środowiska) na objęcie i nabycie akcji, udziałów spółek lub obligacji, których emitentem jest inny podmiot niż Skarb Państwa. Podczas gdy wojewódzkie fundusze zobligowane zostały uzyskać zgodę zarządu województwa jedynie w przypadku zbycia akcji, udziałów spółek lub obligacji takich emitentów. Nie budzą natomiast wątpliwości obowiązki sprawozdawcze, które zostały określone w ust. 5 i 6 art. 411 a p.o.ś. Zarząd Narodowego Funduszu przedkłada w terminie do 30 czerwca ministrowi właściwemu do spraw ochrony środowiska informację o posiadanych akcjach, udziałach bądź obligacjach. Analogiczny obowiązek został także nałożony na zarządy funduszy wojewódzkich z zachowaniem oczywiście właściwości organów, czyli w tym przypadku informacja taka jest składana zarządom województwa.

Zgodnie z tym co zostało już zasygnalizowane powyżej ustawodawca zastrzegł pewne formy finansowania wyłącznie do kompetencji Narodowego Funduszu. Jedynie na szczeblu centralnym możliwe jest udzielanie poręczeń spłaty kredytów oraz zwrotu środków przyznanych przez rządy państw obcych oraz przez organizacje międzynarodowe, z przeznaczeniem na realizację zadań ochrony środowiska i gospodarki wodnej. Zgodnie z postanowieniami art. 411 ust. 5 p.o.ś. udzielenie tego rodzaju zabezpieczenia wierzytelności następuje na zasadach określonych w ustawie z dnia 8 maja 1997 r. o poręczeniach i gwarancjach udzielanych przez Skarb Państwa oraz niektóre osoby prawne. ${ }^{45}$ Mając na uwadze treść art. 33 ust. 1 tej ustawy poręczenia takie mogą być udzielane do wysokości nie wyższej niż $60 \%$ wartości kapitałów (funduszy) własnych, określonych według stanu na koniec roku obrotowego poprzedzającego udzielenie poręczenia, z zastrzeżeniem, że kwota poręczenia udzielanych za zobowiązania określonego podmiotu nie może przekroczyć $20 \%$ wartości tych kapitałów (funduszy). Ustawodawca na mocy art. 32 ustawy o poręczeniach

$44 \quad$ K. Gruszecki, Prawo ochrony środowiska..., op. cit., s. 845.

45 Ustawa z dnia 8 maja 1997 r. o poręczeniach i gwarancjach udzielanych przez Skarb Państwa oraz niektóre osoby prawne (Dz.U. z 2012 r. poz. 657 t.j. z późn. zm.). 
Rola i organizacja Narodowego oraz wojewódzkich funduszy ochrony środowiska...

i gwarancjach udzielanych przez Skarb Państwa oraz niektóre osoby prawne nałożył konieczność odpowiedniego stosowania art. 2b ust. 1 tej ustawy, zgodnie z którym poręczenie takie jest terminowe $\mathrm{z}$ określeniem wysokości odpowiedzialności poręczyciela, czyli kwoty poręczenia. Ponadto na analogicznej podstawie ma zastosowanie art. 8 przywołanej ustawy, zgodnie z którym udzielenie poręczenia jest uzależnione od ustanowienia prawnych zabezpieczeń na wypadek roszczeń z tytułu realizacji poręczenia (są tzw. zabezpieczenia drugiego stopnia).

Narodowy Fundusz jest także uprawniony do przejęcie zobowiązań ministra właściwego do spraw środowiska. Na mocy art. 411 ust. 6 p.o.ś. zobowiązania takie mogą być przejęte, jeżeli przyznanie pomocy przez rządy państw obcych i organizacje międzynarodowe zgodnie z ustaleniami umów międzynarodowych jest warunkowane udzieleniem przez ministra właściwego do spraw środowiska gwarancji zwrotu wypłaconych kwot w całości lub w części, z przyczyn ustanowionych w tych umowach. Formą finansowania dopuszczalną dla Narodowego Funduszu jest także określona w art. 411 ust. 6 a p.o.ś. możliwość obejmowania lub nabywania udziałów lub akcji w spółkach oraz obligacji emitowanych przez inne podmioty niż Skarb Państwa lub jednostki samorządu terytorialnego, za zgodą ministra właściwego do spraw środowiska i ministra właściwego do spraw finansów publicznych, jeżeli jest to związane z rozwojem przemysłu i usług w zakresie ochrony środowiska. Szczególnym przykładem takiej formy finansowania jest Bank Ochrony Środowiska S.A., w którym Narodowy Fundusz posiadał na dzień 30 września 2010 r. $79,10 \%{ }^{46}$ udziału w kapitale zakładowym. ${ }^{47}$

Dla dotychczasowej analizy form finansowania, jakie mogą stosować fundusze ochrony środowiska i gospodarki wodnej kluczowa była zasadnicza regulacja, jaką jest ustawa Prawo ochrony środowiska. W tym miejscu należy jednak poczynić kilka uwag dotyczących pewnych ograniczeń w tym zakresie, jakie wynikają $\mathrm{z}$ innych aktów prawnych. Zgodnie $\mathrm{z}$ art. 411 ust. 8 p.o.ś. fundusze udzielają dotacji i pożyczek oraz przekazują środki (z wyjątkiem nagród, o czym była już mowa wyżej) na podstawie umów cywilnoprawnych. Oznacza to, że strony umowy wiąże normalny stosunek zobowiązaniowy, czyli zgodnie z wynikającą z art. $353^{1}$ k.c. $^{48}$ zasadą swobody, której granice wyznacza właściwość (natura) stosunku prawnego, ustawa oraz zasady współżycia społecznego. Dlatego nie można generalnie wskazać, jakie postanowienia powinna zawierać umowa pożyczki zawierana przez fundusze ochrony środowiska i gospodarki wodnej. Natomiast jak już była o tym mowa wyżej umowy te będą często wymagały bardzo precyzyjnego określenia przedmiotu finansowania czy warunków umorzenia. Jak słusznie wskazuje się w doktrynie ${ }^{49}$ do-

\footnotetext{
$46 \quad$ Za: Raport grupy kapitałowej Banku Ochrony Środowiska S.A. za III kwartał 2010 r., s. 30.

47 S. Urban, (w:) M. Górski, M. Pchałek, W. Radecki, J. Jerzmański, M. Bar, S. Urban, J. Jendrośka, Prawo ochrony środowiska..., op. cit., s. 1366.

48 Ustawa z dnia 23 kwietnia 1964 r. - Kodeks cywilny (Dz.U. z 1964 r. Nr 16, poz. 93).

49 K. Gruszecki, Prawo ochrony środowiska..., op. cit., s. 841.
} 
konując analizy ograniczeń wynikających z ustaw innych niż ustawa Prawo ochrony środowiska, należy mieć na uwadze ustawę z dnia 30 kwietnia 2004 r. o postępowaniu w sprawach dotyczących pomocy publicznej, ${ }^{50}$ która określa m.in. maksymalne poziomy pomocy, jaka może być przyznana przedsiębiorcom. Niezwykle istotne w tym względzie (dla całego systemu finansowania przez fundusze) mogą okazać się także ograniczenia wynikające z ustawy z dnia 29 sierpnia 1997 r. Prawo bankowe. ${ }^{51}$ Wynika to $z$ kilku względów. Po pierwsze, fundusze obecnie współpracują już z sześcioma bankami działającymi na polskim rynku usług finansowych. Po drugie, zgodnie z kluczowym dokumentem dla działalności funduszy, czyli strategią działania na lata 2013-2016 z perspektywą do 2020 r. ma nastąpić „zwiększenie udziału wydatków na finansowanie ochrony środowiska i gospodarki wodnej udzielanych za pośrednictwem partnerów Narodowego Funduszu m.in. właśnie z bankami". ${ }^{52}$ Po trzecie, wreszcie należy wskazać, że dystrybucja środków przez sektor bankowy może odbywać się z wykorzystaniem najistotniejszych form finasowania jak kredyty, pożyczki i dotacje. W ustawie Prawo ochrony środowiska została zawarta wyraźna podstawa prawna wraz z pewnymi unormowaniami dotyczące zasad współpracy funduszy z sektorem bankowym. Zgodnie z art. 411 ust. 10 p.o.ś. zarówno Narodowy, jak i wojewódzkie fundusze ochrony środowiska i gospodarki wodnej mogą udostępniać środki finansowe bankom z przeznaczeniem na udzielanie kredytów bankowych, pożyczek lub określonych rodzajów dotacji na wskazane przez siebie programy i przedsięwzięcia z zakresu ochrony środowiska i gospodarki wodnej oraz potrzeb geologii. Na gruncie tego przepisu zostały także doprecyzowane warunki, tryb wyboru oraz kryteria, jakie powinny spełniać banki współpracujące. $Z$ art. 411 ust. 10a p.o.ś. współpraca na linii bank - fundusz powinna być uregulowana umową, która w szczególności (zgodnie z ust. 10e p.o.ś.) powinna określać tryb i terminy przekazywania środków. Jeśli chodzi zaś o sposób wyboru banków współpracujących to zgodnie $\mathrm{z}$ ust. 10d p.o.ś. wyraźnie wyłączono tutaj zastosowanie ustawy o zamówieniach publicznych. ${ }^{53}$ Pewne wątpliwości może budzić celowość wskazania przez ustawodawcę w art. 411 ust. 10b pkt 1 p.o.ś. minimów kapitałowych, jakie muszą spełniać banki współpracujące, ponieważ jest to de facto powtórzenie w tym zakresie postanowień art. 32 ust. 1 i 2 ustawy Prawo bankowe. Przychodząc na grunt prawa bankowego, które ma zastosowanie w przypadku wykonywania finansowania przez banki należy zwrócić uwagę na pewne aspekty związane $\mathrm{z}$ finansowaniem bankowym, które mogą rzutować na efektywność wykorzystywania środków będących w posiadaniu funduszy. Przede wszystkim należy tutaj zwrócić uwagę na kwestię oceny zdolności kredytowej. Zgodnie z art. 70 ustawy Prawo bankowe

\footnotetext{
50 Ustawa z dnia 30 kwietnia 2004 r. o postępowaniu w sprawach dotyczących pomocy publicznej (Dz.U. z 2007 r. Nr 59, poz. 404 t.j. z późn. zm.)

Ustawa z dnia 29 sierpnia 1997 r. Prawo bankowe (Dz.U. z 2012 r. poz. 1376 t.j. z późn. zm.).

Strategia działania Narodowego Funduszu Ochrony Środowiska i Gospodarki Wodnej..., op. cit., s. 62.

Ustawa z dnia 29 stycznia 2004 r. - Prawo zamówień publicznych (Dz.U. z 2010 r. Nr 113, poz. 759 t.j. z późn. $\mathrm{zm}$.).
} 
Rola i organizacja Narodowego oraz wojewódzkich funduszy ochrony środowiska...

warunkiem udzielenia przez bank kredytu (ale także pożyczki, gdyż przepis ten stosuje się odpowiednio) ${ }^{54}$ jest co do zasady posiadanie przez wnioskodawcę zdolności kredytowej rozumianej jako zdolność do prawidłowej obsługi zadłużenia oraz możliwości przedstawienia prawnych zabezpieczeń wierzytelności. Jest to kluczowy element $\mathrm{w}$ finansowaniu bankowym. Ustawodawca na gruncie prawa bankowego nie określił przesłanek oceny tej zdolności. W konsekwencji to banki indywidualnie określają modele tej oceny, na którą składa się szereg elementów. Można je usystematyzować w obrębie kilku grup. Po pierwsze, będą to dane charakteryzujące kredytobiorcę bądź pożyczkobiorcę poprzez ustalenie jego profilu i okresu działalności, posiadanych kontrahentów, formę prawną, powiązania kapitałowo-organizacyjne czy wreszcie jego „spozycjonowanie” na tle podmiotów prowadzących działalność konkurencyjną. Po drugie, jest to rozbudowana analiza finansowa, której źródłem jest dokumentacja dołączona do wniosku o kredyt bądź pożyczkę. Analiza ta jest wykonywana w odniesieniu do sytuacji bieżącej podmiotu oraz w oparciu o przedstawioną projekcję na okres finansowania. Po trzecie, na ocenę zdolności składa się także prawne zabezpieczenie wierzytelności wynikającej z udzielonego kredytu bądź pożyczki. W praktyce banki przyjmują zróżnicowane zabezpieczenia stosując często ich dywersyfikacje poprzez podział na zabezpieczenia osobowe, rzeczowe ze wskazaniem zabezpieczenia głównego. Przeciętna wartość takiego zabezpieczenia (która jest także określona przez bank za pomocą wewnętrznych wycen) wynosi około 150\% wysokości kredytu bądź pożyczki. Oczywiście należy w tym miejscu zaznaczyć, że kryteria oceny zdolności kredytowej nie są całkowicie dowolnie określane przez banki. Jest to obowiązek publicznoprawny sankcjonowany w ramach uprawnień nadzorczych Komisji Nadzoru Finansowego. ${ }^{55} \mathrm{~W}$ praktyce oznacza to, że przy zastosowaniu przez fundusze ochrony środowiska i gospodarki wodnej formy finansowania w postaci kredytu bądź pożyczki bankowej oraz dopłat do oprocentowania kredytów bądź częściowej spłaty ich kapitału, realną szansę otrzymania tych środków będą miały tylko podmioty, które mogą sfinansować swoje przedsięwzięcie także (udzielonym na zasadach komercyjnych) kredytem bankowym. Może to więc stanowić realne utrudnienie w dostępie do finansowania środkami z funduszy. Naturalnie biorąc pod uwagę priorytet w postaci zwrotnego charakteru tych środków (o czym była mowa już wyżej) także fundusze finansując bezpośrednio dany podmiot muszą określić możliwości zwrotu przekazanych środków. Jednak wydaje się, że kryteria te nie muszą być tak rygorystycznie określone jak w przypadku oceny zdolności kredytowej przez banki. Wszystko więc uzależnione jest od określenia proporcji w stosowaniu poszczególnych form finansowania przez fundusze, tak aby dostęp do tych środków był możliwie najszerszy.

\footnotetext{
54 M. Bączyk, E. Fojcik-Mastalska, L Góral, J. Pisuliński, W. Pyzioł, Prawo bankowe. Komentarz, wyd. 5, Warszawa 2007, s. 278-279.

55 Art. 138 w zw. z 133 ust. 1 ustawy z dnia 21 lipca 2006 r. o nadzorze nad rynkiem finansowym (Dz.U. z 2012 r. poz. 1149 t.j. z późn. zm.).
} 


\section{Podsumowanie}

Warunkiem efektywnych działań w obszarze ochrony środowiska jest zapewnienie odpowiedniego poziomu finansowania $\mathrm{z}$ uwagi na znaczne koszty wielu inwestycji z obszaru ochrony środowiska. W naszym systemie prawnym ustawodawca przesądził o kluczowej $\mathrm{w}$ tym zakresie roli funduszy ochrony środowiska i gospodarki wodnej. Na tle przyjętych w tej regulacji rozwiązań wskazano powyżej na kilka istotnych wątpliwości wynikających zarówno z samej ustawy, jak i przyjętej praktyki, które mogą być istotne dla procesu finansowania. W ramach określenia kompetencji organów zostały unormowania, które mogą powodować rozbieżną interpretację kompetencji poszczególnych organów. Chodzi tu o uprawnienia do zatwierdzania wniosków o pożyczki i dotacji poniżej wskazanych pułapów oraz kompetencje w przedmiocie umorzeń. Na tle źródeł finansowania należy wskazać spadającą efektywność w ściąganiu kar, co może z kolei okazać się szczególnie istotne po wykorzystaniu środków zewnętrznych, zwłaszcza z Unii Europejskiej. Najwięcej trudności może pojawić się na tle wyboru form finansowania. Jak zostało wskazane powyżej pewne formy finansowania mogą okazać się trudne do zastosowania w związku z określonym brzmieniem ustawy. Chodzi tutaj o wskazaną możliwość nabywania udziałów i akcji w spółkach z innym przedmiotem działalności w zamian za nieściągalne wierzytelności wynikające $\mathrm{z}$ umów. Ustawodawca de facto bardzo wąsko określił zakres przedmiotu działalności spółek, w którym fundusz może nabywać udziały, przyjmując, że mogą to być wyłącznie spółki, które prowadzą jednocześnie działalność w zakresie ochrony środowiska, jak i gospodarki wodnej. ${ }^{56}$ Praktycznym problemem w dostępie do środków dla części podmiotów może być także ich dystrybucja z wykorzystaniem sektora bankowego. Może to mieć miejsce $\mathrm{w}$ przypadku finansowania w formie pożyczek i kredytów bankowych bądź dotacji udzielanej w formie dopłat do oprocentowania kredytów bankowych lub spłaty części ich kapitału. Chodzi tutaj przede wszystkim o obowiązki banków w zakresie ustalania zdolności kredytowej. Jak już była o tym mowa wyżej, warunkiem finansowania przez banki jest określenie zgodnie z art. 70 ustawy Prawo bankowe zdolności kredytowej rozumianej jako zdolność do prawidłowej obsługi zadłużenia oraz możliwości przedstawienia prawnych zabezpieczeń wierzytelności. Oznacza to, że dostęp do środków z funduszy dystrybuowanych przy wykorzystaniu tych form finansowania jest ograniczony jedynie dla podmiotów spełniających warunki do finansowania kredytem bankowym udzielonym na zasadach komercyjnych. Oczywiście finansowanie przy użyciu sektora bankowego jest jednym z efektywnych metod wykorzystania środków przez fundusze. Dlatego tak ważne jest zachowanie odpowiednich proporcji do innych (poza związanymi z sektorem bankowym) formami finansowania. 
Rola i organizacja narodowego oraz wojewódzkich funduszy ochrony środowiska...

THE ROLE AND ORGANIZATION OF NATIONAL AND PROVINCIAL FUNDS FOR ENVIRONMENTAL PROTECTION AND WATER MANAGEMENT

The article deals with issues related to the rules of organization and tasks of the National and Provincial Funds for Environmental Protection and Water Management. A detailed analysis has been conducted of the organizational scope of funds, their funding sources and the identification of objectives to be financed. Moreover, the article characterizes financial instruments which are used by funds, with particular emphasis on the principles of financing with the use of a bank credit.

Keywords: National Fund for Environmental Protection and Water Management, financial sources of funds, forms of financing 